\title{
PENGARUH SUPERVISI AKADEMIK, KOMPETENSI GURU, DAN KEDISIPLINAN TERHADAP KINERJA GURU
}

Oleh: Mira Sasmita, Admisistrasi Pendidikan, Fip, Universitas Negeri Padang

mira.sasmita1999@gmail.com

\begin{abstract}
ABSTRAK
Supervisi akademik merupakan bantuan professional kepada guru melalui siklus perencanaan yang sistematis, pengamatan yang cernat, dan umpan balik yang obyektif. Dengan demikian guru dapat memperbaiki kinerjanya untuk meningkatkan mutu pendidikan. Penelitian ini bertujuan untuk mengetahui pelaksanaan supervisi akademik di sma. Dan juga mengetahui pengaruh supervisi akademik, kedisiplinan terhadap kinerja guru di sma.
\end{abstract}

Kata kunci: supervusi akademik, kompetensi, disiplin, dan kinerja guru. 


\section{Latar Belakang}

Mutu pendidikan merupakana salah satu masalah yang dihadapi oleh negera, banyak hal yang yang dijadikan kambing hitaman dalam masalah tersebut, antara lain masalah annggaran pendidikan yang kecil, tidak sesuai dengan yang diamanatkan oleh undang-undang, yaitu APBN, masalah kurikulum pendidikan, kurangnya sarana dan prasarana pendidikan dan rendahnya kualitas guru.

Dalam setiap upaya mutu pendidikan, faktor guru memiliki peranaan yang sangat strategis, dengan demikian upaya peningkatan mutu pendidikan harus didahului dengan upaya peningkatan profesionalisme guru.

Ronald brandt mengatakan: hamper semua usaha reformasi dalam pendidikan seperti pembaruan kurikulum dan penerapan metode mengajar dan pada akhirnya tergantung pada guru. Tanpa mereka menguasai bahan pelajaran dan strategi mengajar, dan tanpa mendorong siswanya untuk mendorong siswanya belajar dengan maksimal untuk mencapai tujuan pendidikan yang efektif.( supriadi.1999).

Menurut (Sussono Hadi, 2009)Pada sekolah- sekolah dalm upaya meningkatkan professional guru, dilakukan supervisi akademik, peningkatan kompetensis dan kedisiplinan yang diharapkan dapat meningkatkan kinerja guru dengan demikian mutu pendidikan disekolah meningkat pula.

Peranan kinerja guru dalam meningkatkan kualitas pendidikan disekolah sangat penting. Kinerja guru yang baik akan menunjang proses pembelajaran yang baik pula. Sehingga akan menghasilkan sumber daya manusia yang baik, dengan demikian kualitas pendidikan peningkat pula. 
Agar kualitas pendidikan terus meningkat perlu diadakan supervisi akademik. Tujuan utama supervisi akademik adalah untuk meningkatkan professional guru dan meningkatkan kualitas pembelajaran. Kompetensi guru juga mempengaruhi kinerja guru, sebab kompetensi guru pada hakikatnya berupa spesifikasi dari pengatuan dari pengetahuan, keterampilan dan sikap yang dimiliki seseorang serta penerapannya didalam pekerjaan.

Untu melaksanakan tugasnya secara professional, seorang guru tidak hanya memiliki kemampuan teknis edukatif, tetapi juga harus memiliki kpribadian yang dapat diandalkan, kedisiplinan, kesadaran untuk melaksanakan tugas, ketepanan dalam melaksanakan tugas, dan ketaatan guru dalam melaksanakan tugasnya juga berperan dalam meningkatkan kinerja guru

Upaya meningkatkan kualitas pendidikan di SMA N 3 slawi dilakukan supervisi akademik oleh kepala sekolah, pengembangan kompetensi guru, penegakan disiplin sehingga diharapkan dapat meningkatkan kinerja guru. Hasil penelitian diharapkan dapat berupa:

1. Manfaat teoritis, sebagai upaya pendalaman keilmuan mengenai permasalahan supervisi akademik, kompetensi guru dan kedisiplinan terhadap kinerja guru SMA 3 slawi kabupaten tegal.

2. Manfaat praktis, untuk memberikan masukan kepada pengambil kebijaksanaan seperti:

a. Dinas pendidikan, memberikan masukan kepada penentu kebijakan dalam upaya meningkatkan mutu guru.

b. Pengawas sekolah, memberikan masukan dalam melaksanakan tugas membimbing guru dalam melaksanakan kegiatan pembelajaran 
c. Kepala sekolah, memberikan masukan kepada sekolah dalam melaksanakan tugas manajerial dan supervisi.

\section{Rumusan masalah}

1. Bagaimana pelaksanaan supervisi akademik, kompetensi guru, kedisiplinan guru terhadap kinerja guru

2. Apakah supervisi akademik, kompetensi guru, dan kedisiplinan berpengaruh secara signifikan terhadap kinerja guru

\section{Tujuan}

1. Untuk mengetahui pelaksanaan supervisi akademik, kopetensi guru, kedisiplinan guru dan kinerja guru

2. Untuk mengetahui apakah supervisi akademik, kompetensi guru, kedisiplinan guru berpengaruh secara signifikan terhadap kinerja guru 


\section{Pembahasan}

Supervisi akademik adalah bantuan professional kepada guru melalui perencanaan yang sistematis, pengamatan, dan umpan balik yang obyektif. Dengan demikian guru tersebut dapat memperbaiki kinerjanya yang kurang tepat untuk meningkatkan mutu pendidikan.

Departemen pendidikan dan kebudayaan (1994) dalam pelaksanaan supervisi pendidikan di sekolah menyebutkan prinsip supervisi adalah:

a. Supervisi bersifat praktis, artinya dapat dikerjakan sesuai situasi dan kondisi sekolah

b. Hasil supervisi harus berfungsi sebagai sumber informasi bagi staf sekolah untuk pengembangan proses belajar mengajar

c. Supervisi dilaksanakan dengan mekanisme yang menunjang kurikulum yang berlaku.

Kompetensi guru merupakan spesifikasi dari pengetahuan, keterampilan dan sikap yang dimiliki seseorang penerapannya didalam pekerjaan sesuai dengan standard kinerja yang dibutuhkan oleh lapangan. Hubungan kompetensi dengan tenaga professional kependidikan yaitu menunjukkan kepada perbuatan yang bersifat rasional dan memenuhi spesifikasi tertentu didalam pelaksanaan tugas kependidikan.

Disiplin pegawai meupakan suatu bentu pelatihan yang berusaha memperbaiki dan membentuk pengetahuan, sikap dan perilaku karyawan sehingga para karyawan tersebut berusaha bekerja secara kooperatif dengan karyawan lainnya serta meningkatkan prestasi kerjanya( siagian:2006). Ada dua jenis disiplin: 
a. Disiplin preventif, yaitu tindakan yang mendorong para karyawan untuk taat kepada berbagai ketentuan yang berlaku dan memenuhi standard yang telah ditetapkan.

b. Disiplin korektif yaitu jika ada karyawan yang nyata- nyata telah melakukan pelanggaran atas ketentuan yang berlaku atau gagal memenuhi standard yang telah ditetapkan, maka akan dikenakan sanksi.

Kinerja Guru menurut KBBI kineja guru merupakan sesuatu yang dicapai oleh guru sebagai tenaga professional. Untuk menjadi professional seorang guru harus memiliki lima hal, yaitu(1) guru mempunyai komitmen pada siswa dan proses belajarnya(2) guru menguasai materi pembelajaran yang diajarkan kepada siswa(3) guru bertanggung jawab dalam memantau evaluasi belajar siswa(4) guru mampu berfikir sistematis tentang apa yang dilakukan atau dari pengalaman(5) guru seyogyanya merupakan bagian dari masyarakat belajar dalam lingkungan profesinya.

pengembangan keprofesionalitasan guru merupakan hal yang penting untuk meningkatkan kualitas pembelajaran seiring dengan perkembangan ilmu pengetahuan teknologi, sosial ekonomi dan budaya masyarakat.

seiring dengan perkembangan manajemen produktifitas juga ditentukan dengan hubungan sosial antara supervisor dan pekerja. Pendekatan supervisi bergerak kearah demoktaris. 
Menurut (sabandi, 2013) Faktor yang mempengaruhi kinerja guru:

1. Motivasi yaitu dorongan untuk melakukan tugas dengan baikyang berasal dari diri seseorang yang memberikan semangat untuk mengerjakan tugas.

2. Etos kerja yaitu apabila seorang pendidik memiliki etos kerja yang baik maka hasil dari pendidikan itu sendiri akan baik.

3. Lingkungan merupakan hal yang sangat mempengaruhi pendidik dalam bagaimana kinerja akan bekerja dengan baik.

4. Tugas dan tanggung jawab seorang guru yaitu bagaimana seorang guru merasa ada tanggung jawab untuk melaksanakan tanggung jawab untuk melaksanakan pembelajaran dengan baik.

Supervisi Pendidikan Untuk Pengembangan Profesionalitas Guru Berkelanjutan alasan supervisor melakukan pelatihan terhadap guru yaitu:

1. Meningkatkan kepuasan dan semangat kerja guru

2. Meningkatkan motivasi guru

3. Meningkatkan efesiensi dalam proses dan hasil yang maksimal

4. Meningkaatkan kapasitas untuk mengadopsi teknologi dan metode baru

5. Meningkatkan inovasi dalam strategi dan hasil

6. Meningkatkan cintra dan lembaga 


\section{A. Pelaksanaan Supervisi Akademik, Kompetensi Guru, Dan Kedisiplinan Guru Terhadap Kinerja Guru Di SMA N 3 Slawi}

Pelaksanaan Supervisi akademik, kompetensi guru, kedisiplinan SMA negeri 3 slawi sudah sangat baik. Karena dalam upaya meningkatkan kualitas pendidikan di SMA N 3 slawi telah dilakukan supervisi yang baik oleh kepala sekolah

. Dapat dilihat dari kuesioner supervisi akademik di sma negeri 3 slawi berkategori baik sekali. Berdasarkan skor perolehan responden diperoleh skor 3495. Berarti memiliki presentase: $(3495: 3900) * 100 \%=89 \%$. Hal tersebut berarti tanggapan tentang pelaksanan supervisi akademik di SMA N 3 slawi kabupaten tegal baik sekali.

Kompetensi guru hasil pengamatan di sma n 3 slawi berkategorikan baik sekali. Berdasarkan skor perolehan kompetensi guru di sma n 3 slawi memperoleh skor 4597, berarti memiliki peresentase $(4597: 5200) * 100 \%=88 \%$.sehingga kompettensi guru-guru SMA n 3 slawi dikategorikan baik sekali.

Dari indicator hasil pengamatan tentang kedisiplinan berkategorikan baik sekali. Berdasarkan skor perolehan variabel kedisiplinan diperoleh skor 2409. Berarti memiliki peresentase $(2409: 2600) * 100 \%=92 \%$. Sehingga kedisiplinan guru-guru sma n 3 slawi dikategorikan baik sekali.

Dari indicator hasil pengamatan kinerja guru berkategorikan baik sekali. Memperoleh skor 3514. Berarti memiliki presentase: $(3514: 3900) * 100 \%=90 \%$.Jadi supervisi akademik, kompetensi guru, kedisiplinan dan kinerja guru-guru sma n 3 slawi sudah sangat baik. 
Jadi pelaksanaan supervisi akademik, kompetensi guru, kedisiplian guru terhadap kinerja guru di SMA N 3 slawi sudah dilaksanakan baik sekali, karena dalam meningkatkan kualitas kualitas pendidikan di sma tersebut sudah dilakukan supervisi yang baik oleh kepala sekolah. Kepala sekolah tersebut mengembangkan kompetensi guru, menegakkan disiplin secara rutin sehingga dapat meningkatkan kinerja guru yang pada akhirnya mutu pendidikan di sekolah tersebut meningkat.

\section{B. Pengaruh Supervisi Akademik, Kompetensi Guru, Kedisiplinan Guru Terhadap Kinerja Guru Di Sma N 3 Slawi}

Supervisi akademik, kompetensi guru, dan kedisiplinan secara bersamasama berpengaruh positif dan signifikan terhadap kinerja guru. Karena variabel supervisi akademik, kompetensi guru dan kedisiplinan dan praktiknya merupakan satu kesatuan yang mempengaruhi kinerja guru, karena ketiga variabel tersebut memiliki kesamaan yaitu, meningkatkan kemampuan professional, meningkatkan kualitas pembelajaran.

Sekolah sebagai Unit Pelaksana Teknis pendidikan jalur sekolah memiliki tanggung jawab melaksanakan pendidikan disekolah selama jangka waktu tertentu sesuai dengan jenis, jenjang, dan sifat sekolah tersebut . dalam melaksanakan kegiatan, sekolah dipimpin oleh kepala sekolah. Kepala sekolah berfungsi sebagai educator, manajer, administration dan supervisor.

Indicator kinerja guru dapat berupa kesadaran guru untuk meningkatkan kemampuan professional, khususnya kemampuan mengajar dan juga keterampilan guru dalam mengajar. Standard kompetensi guru dikembangkan secara utuh dari 
empat kompetensi yaitu: kompetensi pedagogic, kepribadian, sosial dan professional. Ukuran kinerja guru terlihat dari rasa tanggung jawab menjalankan profesinya, tanggung jawab moral dipundaknya.

Kedisiplinan guru mempunyai pengaruh yang paling besar dibandingkan variabel supervisi akademik dan kompetensi gurukarena dengan adanya kedisiplinan yang tinggi guru akan memanfaatkan supervisi akademik dengan sebaik-baiknya dan akan berusaha terus meningkatkan kompetensinya sebagai guru untuk dapat melaksanakan dengan sebaik-baiknya.

Terbentuknya disiplin tersebut tidak akan terjadi dengan sendirinya melainkan harus ditumbuhkan, dikembangkan dan diterapkan dalam semua aspek menerapkan sanksi dan hukuman sesuai dengan perbuatannya.

Prilaku disiplin pegawai pada dasarnya tidak hanya terbatas pada aturanaturan prilaku pegawai dalam melaksanakan pekerjaannya, melainkan jua berhubungan dengan nilai dan norma pilaku tertib dalam kehidupan berkelompok dan bermasyarakat pada umumnya. Sehingga disiplin dikatakan bahwa kepatuhan untuk tunduk kepada keputusan, perintah, dan peraturan yang berlaku. 


\section{Kesimpulan}

dapat disimpulkan pengaruh supervisi akademik, kompetensi guru, kedisiplinan guru, terhadap kinerja guru di sma n 3 slawi adalah:

- supervisi akademik, kompetensi guru, kedisiplinan guru terhadap kinerja guru di sma n 3 slawi sangat baik

- supervisi akademik, kompetensi guru, kedisiplinan guru, terhadap kinerja guru di sma n 3 slwi berpengaru secara positif dan signifikan terhadap kinerja guru.

\section{Saran}

1. lebih meningkatkan dan mengefektifitaskan pelaksanaan supervisi pendidikan, mengingat bahwa salah satu petugas sekolah adalah supervisi akademik terhadap guru.

2. Secara terus menerus menjaga dan meningkatkan kedisiplinan guru dan sekolah melalui berbagai kegiatan atau pengawas yang lebih baik dan intensif.

3. Kepala sekolah hendaknya memilikik kompetensi merencanakan program supervisi akademik yang tepat dalam rangka peningkatan professional guru.

4. Guru untuk Memanfaatkan adanya supervisi pendidikan yang dilakukan oleh atasannya dengan sebaik-baiknya

5. Guru Berupaya meningkatkan kompetensinya melalui berbagai kegiatan. 


\section{Referensi:}

sabandi, a. (2013). Supervisi Pendidikan Untuk Pengembangan Profesionalitas Guru Berkelanjutan. pedagogi, jurnal ilmiah ilmu pendidikan, XIII(2), 1-9.

Sussono Hadi, T. d. (2009). pengaruh supervisi akademik, kompetensi guru dan kedisiplinan terhadap kinerja guru SMA negeri 3 salawi kabupaten tegal. Khazanah Pendidikan, 1-26. 
